\title{
Eosinophilic Esophagitis: Indications for Treatment
}

\author{
Alex Straumann \\ Swiss EoE Clinic and Swiss EoE Research Network, Olten, Switzerland
}

\author{
Key Words \\ Eosinophilic esophagitis · Esophageal remodeling . \\ Esophageal stricture · Food impaction · Quality of life
}

\begin{abstract}
At present, it is still debated whether the focus of treatment in eosinophilic esophagitis (EoE) should be directed toward a symptomatic or histological response, or even toward a combination of both. This question cannot be answered as long as we have no solid data evaluating the long-term consequences of untreated symptoms and untreated inflammation. Nevertheless, today there are at least three established reasons to treat patients with clinically and histologically active EoE. First, dysphagia has a substantial negative impact on the patient's daily life. Despite the fact that patients often cope with this symptom and accept even marked restrictions in their nutritional habits, they usually experience a marked enhancement in quality of life under treatment. Second, untreated EoE harbors the risk of long-lasting food impactions. There is evidence that this unpleasant, unforeseeable and even risky incident can be prevented by efficient treatment of the eosinophilic inflammation. Third, it has been demonstrated in several clinical studies as well as in animal models that unbridled eosinophilic inflammation leads to a so-called remodeling of the esophagus with wall thickening, stiffness of the organ and stricture. Prevention of esophageal damage caused by tissue remodeling is therefore another reason to strongly advocate a consequential treatment. Finally, there is increasing evidence that untreat-
\end{abstract}

ed EoE might be a risk factor for acute infection of the esophagus with herpes simplex virus (HSV), leading to a severe ulcerative and extremely painful esophagitis. Prevention of HSV esophagitis might therefore be a fourth indication for treating EoE.

(c) 2014 S. Karger AG, Basel

\section{Therapeutic Goal in Eosinophilic Esophagitis}

Two decades ago, two case series independently described patients suffering clinically from dysphagia associated histologically with a dense eosinophil infiltration of the esophageal mucosa $[1,2]$. Eosinophilic esophagitis (EoE) was recognized as a novel and distinct clinical entity. At that time the focus of the research was mainly directed toward understanding the underlying mechanism leading to this unusual inflammation and toward the evaluation of the natural course of this disease [3]. As soon as it had become clear that EoE has a chronic course and is numerically a relevant disease, the research interest was additionally drawn toward medical and dietary attempts to treat this inflammation $[4,5]$. Nevertheless, at present, it is still debated whether the focus of treatment in EoE should be directed toward a symptomatic or toward a histological response, or even toward a combination of both [6-8]. This question cannot be answered as long as we have no solid data evaluating the long-term consequences of untreated symptoms and of untreated inflammation.

\section{KARGER}

E-Mail karger@karger.com

www.karger.com/ddi (c) 2014 S. Karger AG, Base

0257-2753/14/0322-0110\$39.50/0
Prof. Dr. med. Alex Straumann

Roemerstrasse 7

$\mathrm{CH}-4600$ Olten (Switzerland)

E-Mail alex.straumann@hin.ch 
Fig. 1. Food impactions. a Endoscopic picture of a 36-year-old male EoE patient experiencing a 6-hour food impaction, showing a ringed esophagus with an impacted bolus in the lower part of the esophagus. b Endoscopic picture of a 24-year-old male EoE patient presenting with an acute food impaction, illustrating the endoscopic removal procedure using a grasp.

Fig. 2. Esophageal strictures. a Endoscopic picture of a 28-year-old female patient with untreated EoE, illustrating a severe inflamed esophagus with edema, white exudates and a stenosing ring in the lower esophagus just above the esophagogastric junction. b Endoscopic picture of a 52-yearold male EoE patient suffering from solidfood dysphagia since almost 30 years, illustrating a severe endoscopically nonpassable stricture in the upper esophagus surrounded by minimally inflamed mucosa.

Fig. 3. Herpes simplex esophagitis in EoE. a Endoscopic picture of a 25 -year-old female patient with previously diagnosed but untreated EoE, suffering currently under odynophagia, showing severe esophagitis with edema and deep ulcers due to esophageal infection with HSV. b Endoscopic picture of a 27-year-old female patient after temporary treatment of EoE 3 years ago, illustrating an ulcerative and necrotizing esophagitis due to infection with HSV.
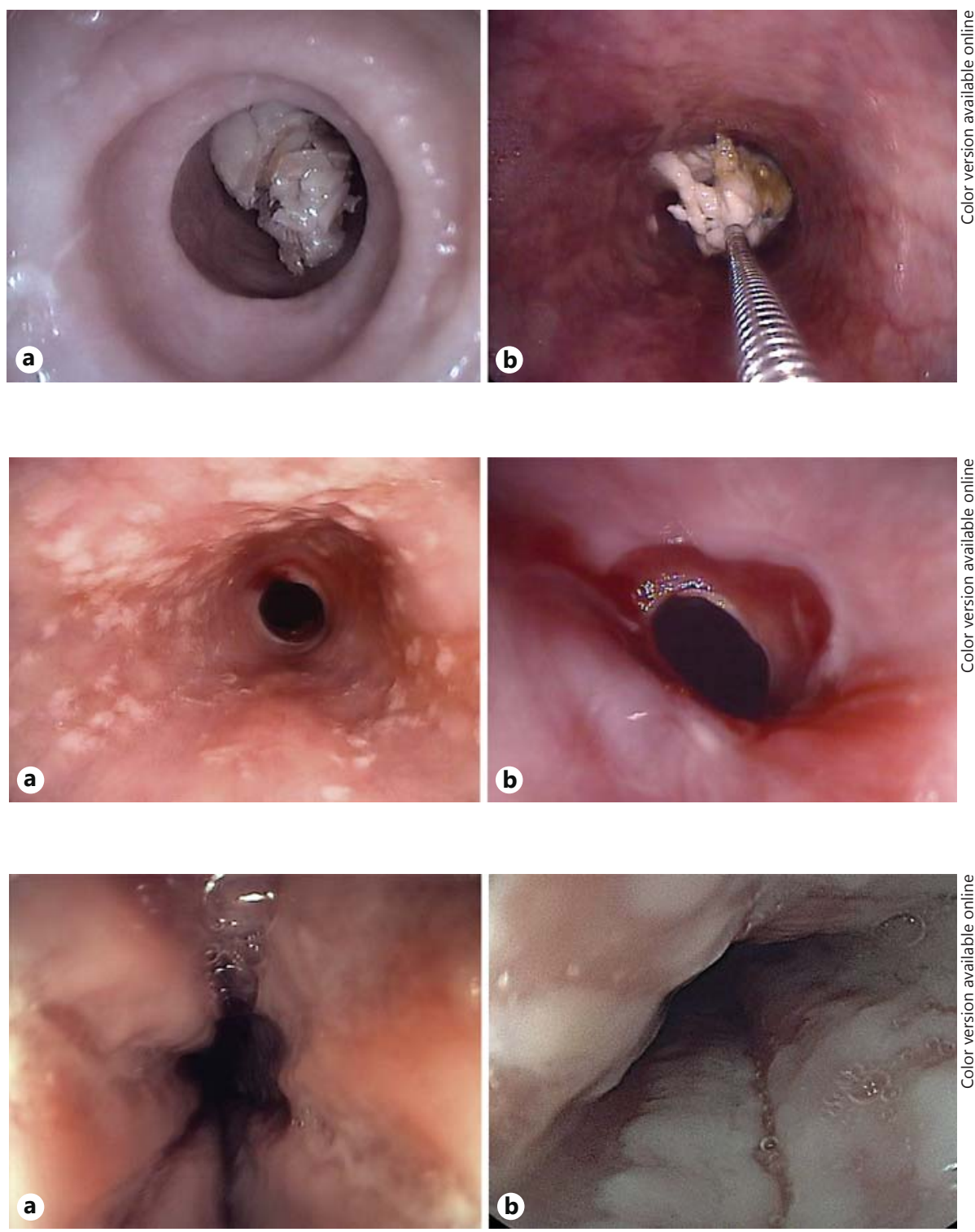

\section{Established Indications for Treatment of EoE}

Solid food dysphagia represents the leading symptom in adolescent and adult EoE [9]. This symptom is reported by approximately $95 \%$ of patients having untreated EoE [6-8]. Because food intake is a daily need and eating is a major enjoyment of human life, swallowing disturbances have a marked negative impact on a patient's daily life and interferes with many professional and social activities [3]. Despite the fact that patients often cope with their symptoms and accept even marked restrictions in their eating habits, they usually experience a marked improvement in their quality of life rapidly after initiation of an efficient treatment. Having once this experience, patients are usually highly motivated to adhere to therapy. Improvement in quality of life is therefore a first indication to treat EoE.

Food impaction is a frequently occurring complication of EoE [6-8]. A retrospective database analysis has demonstrated that 87 (35\%) out of 251 adult patients experienced a total of 134 long-lasting food impactions requiring endoscopic intervention with bolus removal [10]. Almost all of these patients had untreated EoE at the time of impaction (fig. 1) [10]. Of note, impactions are not only unpleasant and unforeseeable for the patients, but additionally harbor a substantial risk of severe esophageal in- 
jury, either retching- or procedure-induced [10]. There is strong evidence that this unpleasant, unforeseeable and even risky incident can be prevented by an efficient treatment of the eosinophilic inflammation. Prevention of food impaction is therefore a second reason to treat EoE.

Furthermore, unbridled eosinophilic inflammation induces fibrosis and angiogenesis in the esophageal wall $[3,11]$. Tissue remodeling has led to a progressive loss of elasticity of the esophagus with luminal narrowing in patients (fig. 2) and in animal models [11-13]. Recently, it has been demonstrated that in untreated EoE, strictures of the esophagus develop in a time-dependent manner [14]. Upon treatment with the topical corticosteroid budesonide, the expression of the fibrosis-related markers, such as TGF- $\beta 1$ and tenascin- $\mathrm{C}$ as well as the degree of fibrosis was markedly decreased in the esophageal tissue [15]. In addition, a number of studies have recently shown that anti-eosinophil treatment can slow or even reverse tissue remodeling [12, 16, 17]. Prevention of esophageal damage caused by tissue remodeling is therefore a third reason for strongly advocating a consequential treatment.

In summary, there are at least three established reasons to treat patients with clinically and histologically active EoE: (1) improvement in the quality of life, (2) reduction in the risk for severe esophageal injury by preventing long-lasting food impactions, and (3) prevention of organ damage caused by the ongoing tissue remodeling.

\section{Nonestablished Indications for Treatment of Eosinophilic Esophagitis}

In the last few years, several cases of severe ulcerative esophagitis caused be herpes simplex virus 1 (HSV1) have been reported $[18,19]$. Of note, all of these infections occurred in young immunocompetent patients suffering from EoE (fig. 3). The majority of these patients had untreated EoE. Herpes simplex esophagitis is a rare clinical manifestation of HSV1 primary infection or of a reactivation of previously acquired HSV1. It occurs typically in immunocompromised individuals. In contrast, in immunocompetent otherwise healthy individuals, HSV1-induced esophagitis is a rarity. It is therefore tempting to speculate that active eosinophilic inflammation of the esophageal squamous epithelium might be a risk factor for acquiring infections with HSV. Prevention of HSV esophagitis might therefore be another indication for treating EoE.

Considering EoE has only been known for a short time, it is likely that other reasons for treating EoE will be added to this list.

\section{Disclosure Statement}

The author has no conflicts to declare regarding this article.

\section{References}

1 Attwood SE, Smyrk TC, Demeester TR, Jones JB: Esophageal eosinophilia with dysphagia, a distinct clinicopathologic syndrome. Dig Dis Sci 1993;38:109-116.

- 2 Straumann A, Spichtin HP, Bernoulli R, Loosli J, Vögtlin J: Idiopathic eosinophilic esophagitis: a frequently overlooked disease with typical clinical aspects and discrete endoscopic findings (in German with English abstract). Schweiz Med Wochenschr 1994; 124:1419-1429.

-3 Straumann A, Spichtin HP, Grize L, Bucher KA, Beglinger C, Simon HU: Natural history of primary eosinophilic esophagitis: a followup of 30 adult patients for up to 11.5 years. Gastroenterology 2003;125:1660-1669.

4 Liacouras CA, Wenner WJ, Brown K, Ruchelli E: Primary eosinophilic esophagitis in children: successful treatment with oral corticosteroids. J Pediatr Gastroenterol Nutr 1998; 26:380-385
5 Kelly KJ, Lazenby AJ, Rowe PC, Yardley JH, Perman JA, Sampson HA: Eosinophilic esophagitis attributed to gastroesophageal reflux: improvement with an amino acid-based formula. Gastroenterology 1995;109:15031512.

6 Furuta GT, Liacouras C, Collins MH, Gupta S, Justinich C, Putnam P, Bonis P, Hassall E, Straumann A, Rothenberg ME: Eosinophilic esophagitis in children and adults: a systematic review and consensus recommendations for diagnosis and treatment. Gastroenterology $2007 ; 133: 1342-1363$.

7 Liacouras CA, Furuta GT, Hirano I, Atkins D, Attwood SE, Bonis PA, Burks AW, Chehade M, Collins MH, Dellon ES, Dohil R, Falk GW, Gonsalves N, Gupta SK, Katzka DA, Lucendo AJ, Markowitz JE, Noel RJ, Odze RD, Putnam PE, Richter JE, Romero Y, Ruchelli E, Sampson HA, Schoepfer A, Shaheen NJ, Sicherer SH, Spechler S, Spergel JM, Straumann A,
Wershil BK, Rothenberg ME, Aceves SS: Eosinophilic esophagitis: updated consensus recommendations for children and adults. J Allergy Clin Immunol 2011;128:3-20.

8 Straumann A, Aceves SS, Blanchard C, Collins MH, Furuta GT, Hirano I, Schoepfer AM, Simon D, Simon HU: Pediatric and adult eosinophilic esophagitis: similarities and differences. Allergy 2012;67:477-490.

9 Noel RJ, Putnam PE, Rothenberg ME: Eosinophilic esophagitis. New Engl J Med 2004; 351:940-941.

10 Straumann A, Bussmann C, Zuber M, Vannini S, Simon HU, Schoepfer AM: Eosinophilic esophagitis: analysis of food impaction and perforation in 251 adolescent and adult patients. Clin Gastroenterol Hepatol 2008;6:598-600.

11 Aceves SS, Dohil R, Newbury RO, Bastian JF: Topical viscous budesonide suspension for treatment of eosinophilic esophagitis. J Allergy Clin Immunol 2005;116:705-706. 
12 Straumann A, Conus S, Degen L, Frei C, Bussmann C, Beglinger C, Schoepfer A, Simon HU: Long-term budesonide maintenance treatment is partially effective for patients with eosinophilic esophagitis. Clin Gastroenterol Hepatol 2011;9:400-409.

13 Mishra A, Wang M, Pemmaraju VR, Collins MH, Fulkerson PC, Abonia PJ, Blanchard C, Putnam PE, Rothenberg ME: Esophageal remodeling develops as a consequence of tissue specific IL-5-induced eosinophilia. Gastroenterology 2008;134:204-214.

14 Schoepfer AM, Safroneeva E, Bussmann Ch, Kuchen T, Portmann S, Simon HU, Straumann A: Untreated eosinophilic esophagitis leads to stricture formation in a time-dependent manner. Gastroenterology 2013, E-pub ahead of print.
15 Straumann A, Conus S, Degen L, Felder S, Kummer M, Engel H, Bussmann C, Beglinger C, Schoepfer A, Simon HU: Budesonide is effective in adolescent and adult patients with active eosinophilic esophagitis. Gastroenterology 2010;139:1526-1537.

16 Aceves SS, Newbury RO, Chen D, Mueller J, Dohil R, Hoffman H, Bastian JF, Broide DH: Resolution of remodeling in eosinophilic esophagitis correlates with epithelial response to topical corticosteroids. Allergy 2010;65: 109-116.
7 Lucendo AJ, Arias A, De Rezende LC, YagueCompadre JL, Mota-Huertas T, GonzalezCastillo S, Cuesta RA, Tenias JM, Bellon T: Subepithelial collagen deposition, profibrogenic cytokine gene expression, and changes after prolonged fluticasone propionate treatment in adult eosinophilic esophagitis: a prospective study. J Allergy Clin Immunol 2011; 128:1037-1046.

18 Squires KA, Cameron DJ, Oliver M, et al: Herpes simplex and eosinophilic esophagitis: the chicken or the egg? J Pediatr Gastroenterol Nutr 2009;49:246-250.

19 Franulovic OZ, Lesar T, Busic N, Tesovic G: Herpes simplex primo-infection in an immunocompetent host with eosinophilic esophagitis. Pediatr Int 2013;55:38-41. 